\title{
JOURNAL.RU
}

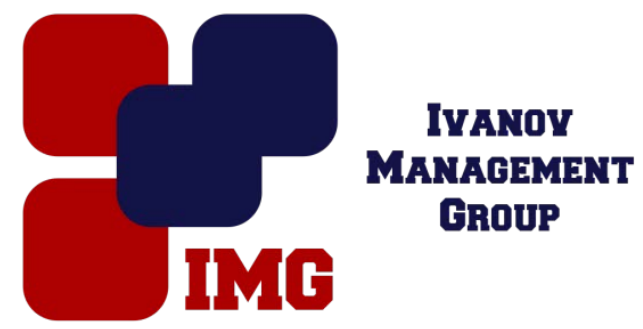

Раздобреева Я.В. Иркутский национальный исследовательский технический университет Иркутск, Россия

doi: 10.18411/lj-30-04-2017-2-14

idsp 000001:lj-30-04-2017-2-14

\section{Проблемы сохранения и трансформации промышленного наследия}

\section{Аннотация}

В статье раскрываются проблемы современного состояния объектов промышленного наследия. Затрагиваются вопросы трансформации территорий бывших промышленных комплексов.

Ключевые слова: трансформация промышленного наследия, индустриальное наследие, промышленность, сохранение промышленного наследия.

В последние десятилетия вопросы сохранения и трансформации индустриального наследия приобрели в мире и в России большую значимость и актуальность. Движущими силами этих процессов стали стремительные изменения в производственной сфере, когда общество в передовых странах переходит от индустриальной к постиндустриальной эпохе, промышленные предприятия закрываются, и встает вопрос, что делать дальше с их зданиями и оборудованием.

Концепция «индустриального наследия» возникла относительно недавно и претерпела некоторые изменения с течением ряда лет. Важнейшую роль в формировании научного определения данного явления сыграл Международный комитет по сохранению индустриального наследия (ТІCCIH), который широко обсуждал эту проблему и выработал четкое определение этого понятия. Таким образом, материальное культурное наследие, частью которого является индустриальное наследие, определяется как совокупность строений и 
артефактов, произведенных обществом с использованием труда и нуждающихся в сохранении для будущих поколений. [1]

После распада СССР большинство промышленных объектов пришли в запустение. Так, Иркутск до начала 1990-х годов оставался одним из крупнейших индустриальных центров РСФСР с высокотехнологичным машиностроением, ориентированным на союзный рынок: развивалось авиастроение, приборостроение, радиоэлектроника; а также производство металлургического и горного оборудования, автомобильных деталей и станков. Металлообрабатывающее производство было представлено заводами по ремонту подвижного состава железной дороги, речных судов, самолётов. Другими крупными отраслями были производство строительных материалов, мебельная, полиграфическая, лёгкая и пищевая промышленность. [2]

На сегодняшний день многие производственные здания находятся в заброшенном, ветхом состоянии и продолжают разрушаться, некоторые заводы, пережив волну приватизации, переоборудованы в многочисленные торговые центры с полным изменением архитектурного облика. Некоторые примеры современного использования промышленных объектов Иркутска:

- Завод Куйбышева - рынок "Фортуна".

- Завод "Эталон" - салон мебели "Шатура".

- Завод карданных валов - торговый центр "Иркутский".

- Релейный завод - торговый центр "Манеж".

- Кондитерская фабрика "Иркутская" - трц «Карамель»

- Чаеразвесочная фабрика - корпуса продаются.

- Радиозавод - тц «Джем Молл»

- Слюдяная фабрика - офисное здание.

Современное состояние охраны в области индустриального наследия близко к критическому, несмотря на некоторые положительные тенденции. Концепции трансформации не существует, переоборудование происходит с точки зрения наибольшей экономической выгоды для владельца. Никаких льгот, стимулирующих сохранять памятники промышленности не предусмотрено.

Мировая практика сохранения объектов промышленного наследия обычно предусматривает два подхода: прекращение деятельности предприятия и трансформация его в музей с некоторыми дополнительными функциями. В таком случае наиболее ценные элементы конструкции, архитектурного облика, 
оборудования сохраняются. В последнее время набирает популярность перепрофилирование фабрик под жилые помещения премиум-класса.

Большой опыт сохранения памятников промышленности у немецких специалистов. Федеральная палата инженеров Германии присваивает знаковым инженерным сооружениям статус исторического памятника. К инженерному сооружению выдвигается ряд требований: возраст сооружения более 50 лет, оно должно занимать важное место в становлении гражданского строительства и сохранить свои выдающиеся качества до настоящего времени.

В настоящее время семью экспертами научно-консультативного совета Федеральной палаты инженеров составлен список из 70 объектов, достойных называться историческими памятниками. По состоянию на начало 2013 г. статус присвоен одиннадцати выдающимся инженерным сооружениям. [3]

Многие всемирно известные объекты промышленного наследия Норвегии, Германии, Японии и Ирландии входят в список всемирного наследия ЮНЕСКО. Предприятия тяжёлой и гидроэнергетической промышленности, с их рабочими посёлками и транспортной системой имеют особую, историческую и культурную значимость. Благодаря включению в список ЮНЕСКО уникальные в своем роде объекты приобретают известность и находятся под особой защитой.

На сегодняшний день для сохранения индустриального наследия в России необходим системный подход по определению ценности объекта индустриального наследия, позволяющий оптимизировать меры, направленные на сохранение наиболее важных объектов.

Мировой опыт доказывает, что при комплексном подходе, учитывая многие историко-архитектурные, инженерные и социально-культурные факторы при сохранении и трансформации индустриального наследия, можно избежать многих ошибок.

$* * *$

1. Запарий В.В. Индустриальное наследие (к вопросу о понимании данной концепции в России и за рубежом) // Экономическая история. Обозрение. Вып. 13 / по д ред. Л.И. Бородкина. М., 2007 (Тр. ист. ф-та МГУ; вып. 39). С. 211 - 217.

2. Тараканов, Михаил Александрович. Промышленность Приангарья: область и столица / М. А. Тараканов, М. М. Гусева. - С .60-71.

3. Исторические памятники инженерно-архитектурного искусства Германии [Электронный ресурс]. - Режим доступа: http:// wikipedia.org. 